(малювання), а контрольна група навчалася за звичайним навчальним планом без будь-яких змін. Методика, за якою навчалися діти експериментальної групи, була розроблена Вільямом Гордоном та колегами, яку було адаптовано для дошкільників. Вона включає такі 9 секцій: малювання на вільну тему; малювання довільних ліній; малювання на задану тему: люди, тварини, фрукти, квіти; ілюстрація за оповіданням; завершення незакінчених малюнків; гравюра а) на натуральних матеріалах, б) на синтетичних матеріалах; поєднання малювання та майстрування; поєднання малювання з тренуванням сприйняття на слух; поєднання малювання 3 вигадуванням історій та їх презентацією. Кожна секція розрахована на 30-60 хвилин. Окрім цього, також було використано Тест на креативність (автор - Абеді), який складається з 30 запитань та може використовуватися для будьякого віку. За результатами експерименту було виявлено, що малювання дійсно позитивно впливає на розвиток креативності дітей. Окрім цього, також було досліджено такі якості дітей, як гнучкість, ініціативність та вміння малювати як складові креативності. За усіма показниками після проведення експерименту діти експериментальної групи випереджали дітей контрольної. Тож рекомендовано до навчальної програми дошкільників у дитячих садочках додавати уроки мистецтва, зокрема малювання.

Ключові слова: малювання, креативність, вміння малювати, розвиток, ініціатива, гнучкість, дошкільники.

Подано до редакиіï 21.12.2016

UDC: $373.2+159.954$

\author{
S. Zahra Shahnemati, \\ Master-Degree student, Department of Educational Science, \\ Islamic Azad University, Isfahan (Khorasgan) Branch, \\ Isfahan, Iran, \\ Zohreh Saadatmand, \\ associate professor, Department of Curriculum Planning, \\ Isfahan (Khorasgan) Branch, Islamic Azad University, Isfahan, Iran, \\ Narges Keshtiaray, \\ associate professor, Department of Educational Sciences, \\ Islamic Azad University, Isfahan (Khorasgan) Branch, Isfahan, Iran
}

\title{
PHENOMENOLOGY OF TEACHERS' EXPERIENCE IN TEACHING ART TO PRIMARY SCHOOL STUDENTS
}

The study is aimed at investigating teachers' experience of teaching Art at primary school. The survey involved Art teachers in Marvdasht and Shiraz cities in Fars Province. The participants were selected using snowball sampling method. Deep semi-structured interviews were used to collect information. The data analysis has been performed by thematic coding. The results have shown that the teachers use such teaching methods as working in small groups, role playing, group discussion, etc. in their practice. Considering the fact that the major part of knowledge is learned by students in the classroom the teaching quality is one of the most important factors in student' achievements. Thus, teachers should strive to improve the quality of teaching.

Keywords: methods of teaching Art, teaching skills, Art lessons, teaching experience.

Introduction. Many psychologists and education specialists deal with the searching for ways to develop and improve the educational process in general and teaching methods in particular. Despite numerous researches in this area, the results are varying due to various affecting factors in the field of teaching methods so that educators do not come up to a conclusion about one specific teaching method which would improve the educational process. Preparing students for living in today's difficult and complex conditions requires the improvement of the quality of teaching and learning expertise. Paying thorough attention to the teaching experience of teachers around the world is one of the strategies to meet the needs of the education in every country.
Art is one of the most mysterious aspects of human culture and civilization that always pervades human life. According to Lancaster (1990), art is a part of the human creativity through which people communicate with each other. Art includes that part of human creativity through which human beings transfer their feelings, thoughts and emotions expressed in visual interpretation of the environmental experiences to others using artistic tools and handicrafts. However, the success in this field depends on artistic features of a person (Amini, 2006).

From the dawn of human history, art, in its various forms, has had a significant role in human life so that it can be said that human beings have stated their inner desires, attitudes, emotions and creativity even through 
the carvings on the walls of caves and made them as lasting expression through art and the creation of beauty (Curtis and Aspaykr, 1996). As a result of scientific and cultural developments of Renaissance and intellectual effort of scholars such as Bacon and Descartes, the realm of education also underwent major changes. In this regard, Cominus, who used thoughts and scientific experiences of Bacon in education, excessively emphasized the education of senses and using painting as a means to transform school education from the difficult and hard process to a pleasant one, so he is a pioneer in pre-school education in the field of developing senses that connect the child with the world of art (Naghibzadeh, 1995).

Art training is considered as one of the basic and important disciplines in the educational system. Its significance is caused by the fact that art education emphasizes the creation and development of the productive areas such as creativity, cognitive and intellectual skills, emotional education and adjustment, creating deep changes in personal behavior, moral development, increased selfconfidence, developing skills of manipulation and so on. That is why different intellectual, political and religious schools have known art as an efficient tool in the development of various concepts and knowledge in the society and have used it in education in an appropriate manner with their objectives (Mirzabeygy, 2011). In the framework of non-instrumental view of Art in the educational system, it is known as an independent educational discipline. There is no discrimination between art as a subject and other confirmed courses in the curriculum (Mehrmohammadi, 2011). Art curriculum, unlike other basic courses, is not limited by certain rules and norms. Art is a realm in which students continuously face problems which cannot be unambiguously solved and are different from the ones they face in other subjects.

Teaching Art is a unique, interesting but rather difficult profession. According to some scholars, the biggest mistake of teaching art disciplines is allowing students enjoy various kinds of art in the classroom without any purpose. Art education is involved in the development of thinking skills, creativity and the formation of values. It has the ability to invoke the individuals for learning and overcoming barriers and negative emotions; as well as to reduce and eliminate damaging effects such as disinterest, anxiety and fatigues and make the development of human values possible through artistic activities (Eisner, 2002). The experience of learning art creates abilities in a child that affect his/her relations with peers, teachers and family. In the process of studying art, children learn to respect different views, consider people's ideas, listen to others, compromise and control their social skills in the service of a more general artistic view (Dizzy, 2002). Teachers, as the main elements of Art education process, have a dominant role, so the study of the Art teachers' experience can illuminate the challenges of teaching Art in primary schools. Primary school students should be able to learn basic skills, express their needs and desires and understand the thoughts and feelings of other people, as well as take a position in the creation of emotional relationships with others. In this regard, the content of Art curriculum is the first step towards the development of basic skills. Art course provides the opportunity for the development of aesthetics and creativity and the facilitation of learning other subject matters, free expression of feelings, exploration of the emotional and behavioral problems, self-expression and personal experience, stylization of emotions, intellectual cooperation, the development of values and so on.

The study aims to investigate the interpretation of primary school teachers' experience in Art teaching in order to improve the process of teaching Art subjects to primary school students. The results of this study can also be useful in overcoming some education difficulties on the way of increasing knowledge and skills of teachers regarding the abilities of students.

\section{Teaching methods}

Teachers provide students with new skills and knowledge using various teaching methods (Maleki, 2007). Therefore, proper teaching methods are necessary in each of the following areas of artistic production: Art History, Art Criticism and Aesthetics.

\section{A: Teaching methods of artistic production}

Given that artistic production is related to various artistic activities and workshops in the field of visual arts, the teaching methods and learning opportunities associated with visual arts are at the center of attention. In all activities related to the Art curriculum in general and in the areas of visual arts in particular, students should take advantage of many opportunities to act, build and create, observe and enjoy. The collection of designed activities and teaching methods in the field of visual arts should increase the skill levels, functional and scientific capabilities of students in the creation and building areas as well as the development of cognitive and understanding abilities, art criticism, creating historical views and assessing artistic works.

B: Teaching methods of art criticism in the field of teaching Art Criticism (Horowitz et al., 1991) can be summarized (Table 1.) as follows:

The characteristics of modern teaching methods of Art Criticism (Horowitz et al., 1991)

Art Criticism teaches making judgments about artistic phenomena.

Different learning tools like slides, books, photos, pictures, videos and all original works of art, visiting museums, galleries and meeting local artists are used. Among different forms of visual arts, fine arts (painting, sculpture), applied arts (architecture, industrial design) and handicrafts are used. It is also possible that the mass media means (videos, films, newspapers, magazines, etc.) are brought to the class.

Art Criticism minimizes discussion of history and biography of artists and focuses on the works of art. 
Due to the methods and functions of Art Criticism, it can be concluded that knowing aesthetics is possible through artistic criticism and the background for the education of the visual and sensory characteristics of artistic phenomena and the comparison and opposition of works together are provided. Moreover, understanding the position and importance of artistic achievements as cultural products, understanding social norms and values and evaluation of various forms of artistic activities will be competently realized through art criticism. Thus, it is essential that in the curriculum of art, backgrounds and opportunities to grow the capabilities of students to be critical are provided. In this regard, some appropriate teaching methods to learn Art Criticism are pointed out (Horowitz et al., 1991):

1. Comparative method: in four stages of Art Criticism, four basic questions will be discussed:

- What can you see in the artwork? (Describe)

- How are things put together? (Analysis)

- What is the artist trying to say? (Comments)

- What do you think about this work of art and why? (Judge)

So these questions should be involved in the process of teaching Art Criticism to children.

2. The use of criticism in primary school: the teacher can manage class discussion using comparative approach and strengthen criticism skills in students. In this way, the techniques of artistic works can be compared in the class. Thus, children learn how to be aware of the unique features of an artwork.

3. The use of heuristic method: students are encouraged to discover specific bases for their criticism. In the verge of heuristic discussions, the teacher changes the students' words into technical terms and recalls the important forgotten characteristics to them.

4. The development of a linguistic (speech) basis: in this method, the teacher can classify the required artistic words corresponding to the educational unit, course, and academic year for students to learn. These words must have the same consistency in the work of art. Students can then appropriately apply these artistic words to works of art wherever they want after learning each word. This new critical language helps teachers to better assess students' academic achievements.

5. Word adaption: in this method, the teacher can code each word in the list on a card and ask students to compare the adaptive part of that word with the work of art. Also, he/she can ask students to write new words on the board and make use of colorful chalks to classify them by sticking the work of art to the board. Students, in this way, can classify the words associated with formal elements, design principles, expressive features and other elements of works of art.

6. Imagining words basing on emotions: the teacher can write words that represent different emotions (sad, happy, comfortable, angry, calm, pleasant, high-spirited, quiet) on special cards and distribute them among students. Then, each student can create a work of art in the form of drawing, painting, sculpture and so on related to words. After that, the teacher will show the work of art to the class and the students will be asked to identify words associated with it.

7. Artist of the Week: the teacher can start a lesson by introducing the artist of the Week and present interesting information about him/her and his/her works to students. Accordingly, the teacher can pose questions in the fields of description, analysis or interpretation and play artistic works in the form of a big art gallery in the classroom.

8. Showing artistic subjects: teachers can teach artistic criticism skills in both visual and verbal methods through displaying works of art. The teacher can stick the similar works of art of different countries on the wall for a while and ask students to describe what they have learned from the pictures after some days. The students can learn the concepts of portrait, similarities and differences of style and so on by their own interpretations.

9. Interaction with workshop activities: as far as possible, art education should be done in association with workshops and art projects. When students work on a visual or technical problem, they can learn more from other artists who work in this area. In this way, students learn how, as other artists, they can make their art work more realistic with similar efforts.

10. Group collaboration: although talking about the work of art is a main strategy in art criticism, non-verbal activities should be also considered. Due to time constraints, it is impossible for all individuals to comment. In this regard, some verbal and nonverbal strategies can be useful. Students' comments can be received in separate tabs. This approach seeks to achieve the following four objectives:

- explaining works of art through their artistic terminology and identifying the design, meanings and media in them;

- increasing students' level of artworks perception;

- improving students' ability to perceive visual elements of works of art;

- developing the ability to think, associate and form hypotheses based on observations.

\section{C: Methods of teaching Art History}

1. Organizing mental images. One of the most effective methods of teaching Art history is the image lines using a world map in the class. Although young children do not have a complete image of the concepts of time length such as centuries or decades, they can identify the differences regarding the distance with "current time" from time tables. Many primary school children cannot differentiate the geography or the world cultures, but they can observe the situation differences on the map and their understanding of the situation will be improved as they grow up. The teacher can ask students to identify the place and time zone for each of the works of art by displaying different works of arts related to different cultures. Repeating this process, the teacher helps students to finally distinguish the different art styles in different societies and cultures. Also, the teacher can recall the type of works of arts to students by writing the name of art- 
works such as drawing, painting, sculpturing and so on and sticking them to the board. All these strategies in teaching Art History can help teachers guide students in order to achieve the determined objectives of teaching.

2. The explanation of artistic objectives: using this method, the teacher tries to make students aware of the objectives of specific works of art (the process is naturally associated with certain historical background). Understanding different objectives of creating a work of art, although seems to be simple, improves aesthetic skills as an important basis of art education.

3. Data resources: in this approach, different data resources such as articles, books, pictures, videos and other resources about a specific topic are collected and placed in a special folder. The teacher can give each of these folders to one of the groups in the class and ask them to answer fundamental questions about the works of art. Finally, he/she provides a report summary on the subject for the whole class and asks students to express their opinions on the report.

4. Workshop activities: when primary school students actively participate in workshop and practical activities, they get more interested in art history. The teacher can purposefully provide the content of art history and manage the discussion and dialogue among students by guiding them and share it with all the class. Teachers can organize classroom art activities based on heuristic methods of art historians.

5. Documents: teachers can display paintings in the greeting cards or magazine pictures on boards and put a number next to each work of art. Then, the students are given the information that several of the works belong to one. Students are then asked to recognize and discuss them as well as present their arguments.

6. The historical interpretation of Art subjects: teachers can gather a collection of works of art such as books, slides and post cards around a subject matter such as animals and ask students to classify the works and identify their common subject. The teacher can ask the students to accomplish the following tasks based on their age:

- identify the materials and process used in each of the works of art

- identify the roots of art and artist in the work of art

- identify the location of creating a work of art and its current whereabouts

- identify current owner of the artwork

- describe the specific purpose of creating a work of art

- compare the works of art based on the time of their creation

7. The determination of chronology of creating works of art: in this approach, the teacher can ask students which work is chronologically first and which one is the next using a collection of works of art. The teacher can control the difficulty of this activity by the careful selection of the works of art.

8. The approach of archeology puzzles: some art historians increase their knowledge using archaeology techniques about the art objects of the ancient civiliza- tions and create a work of art by collecting parts of a puzzle to build a complete picture of the artwork. Also, the students are asked to explain their reasoning for picking up the pieces of art. This means to explain their choice by color, size, pattern, or texture.

9. Reading about the history of art: reading is an important kind of activities for students. There are many highquality art history books for children. School libraries should prepare books about art along with other subjects in the curriculum and make art journals available to students. Senior primary school students can do library research in the field of art history and write related articles. In this way, students can learn as art historians to do a research.

10. Deep experience: the allocation of adequate time for a work of art can provide the students with the opportunity to pass its superficial level and go deep into it. This requires teachers to have discussion with students about the era, its artist and the general cultural context within which the work is created. When a deep approach to the study of a work of art or an artist is employed, it can be expected to have some sort of movement, style, or the basis for the work of art.

11. Role-playing: students are can better learn the concepts of art history through dramatic activities. They can collect symbols, pictures or videos of artistic events and the teacher can ask the students to choose an artist and dress like him/her and play a show in the class. Then other students have to guess the artist. The teacher can give students the chance to ask nearly 20 questions in order to get near to the answer. This method requires the students to have information about the artist.

12. The use of historical theory as a link between criticism and art history: in the process of art criticism, the analysis stage requires the critics to pay attention to the elements and bases forming the work of art. At higher levels of analysis, stylistic differences between two or more historical periods are compared. In this type of analysis, it is required to consider elements such as linearity, closed or open combination of works, color and lighting in a work of art (Horowitz et al, 1991).

\section{Aesthetics teaching methods}

One of the methods of teaching aesthetics to children, and especially to primary school students, is exploration and structural discussion.

Some research and inquiry practices exist at the heart of some of the fields of art such as aesthetics. When the interview goes beyond the share of informal personal opinions, it is changed into a process called exploration. Exploration is the search for the best answers through the process of questioning. When art is interpreted, when the deeper meanings of a work of art are studied, in all these cases, the exploration process will be experienced. Structured exploration includes logically accepted rules called dialectic approach. It is a form of structured dialogue (Horowitz et al, 1991). In order to implement this approach successfully, the instructions below are significant (see Table 3). 
Table 3.

Aesthetic teaching methods features (Horowitz et al, 1991)

\begin{tabular}{|c|}
\hline Lesson plan is regulated basing on several main questions on the subject. \\
\hline Yes-no questions should be avoided due to the limited opportunities for discussion. \\
\hline $\begin{array}{l}\text { The memorization of definitions from texts or dictionaries cause the vagueness of comprehension and } \\
\text { early forgetfulness so, they should be avoided. }\end{array}$ \\
\hline $\begin{array}{l}\text { The clear and obvious questions should be used instead of complex ones to attract shy or less motivated } \\
\text { students. Any student does not like saying "I don't know". }\end{array}$ \\
\hline Questions including answers should be avoided since they do not help students to learn. \\
\hline It is better to encourage children to discuss their contradictory ideas with other students. \\
\hline $\begin{array}{l}\text { In the exploration process, it is better for the teacher to use clear and obvious questions since it is the } \\
\text { nature of the question that shows the students' answers are exact or misleading. }\end{array}$ \\
\hline $\begin{array}{l}\text { The teacher can use final summary at the end of each section to make students understand next explora- } \\
\text { tion stages better. }\end{array}$ \\
\hline The students' answers expressing agreement or disagreement are discussed with the rest of students. \\
\hline $\begin{array}{l}\text { Class discussion can be done about all aspects of the lesson and the teacher should not be focused only on } \\
\text { some of the students. }\end{array}$ \\
\hline $\begin{array}{l}\text { Group cooperation should be used as a part of the exploration teaching method. In this regard, the class is } \\
\text { divided into some groups and the group agent will give the answers to the class. }\end{array}$ \\
\hline The teacher can assess the common opinions of students regarding each student's idea individually. \\
\hline $\begin{array}{l}\text { Exploration process is not possible without the guidelines. The teacher can regulate some rules before } \\
\text { starting the lesson. }\end{array}$ \\
\hline $\begin{array}{l}\text { Although aesthetics emphasizes what was mentioned not what was seen, the ideas which are chosen for } \\
\text { discussion should be related to works of art. }\end{array}$ \\
\hline $\begin{array}{l}\text { The main objective of the aesthetics exploration is the development of the ability to confront disagree- } \\
\text { ments and hesitations of students. This ability helps them to consider each problem in a different way. }\end{array}$ \\
\hline
\end{tabular}

Aesthetics as one of the fundamental aspects of the artistic education seeks to create positive and constructive feelings and emotions in students showing their acknowledgment and value towards art and works of art.

Therefore, the present study seeks to answer the following question: What teaching methods are most often used by primary school Art teachers?

Research method. The data about teachers' experience of teaching Art was collected by semi-structured interviews. The surveyed were asked the following questions:

1. Could you please describe a session of Art lesson?

2. Which Art lesson session was the most memorable for you?

3. What kind of Art lesson session do the students enjoy most?

The information was analyzed through thematic coding. The steps in this approach are the following:

1. Choosing a Theme

2. Preparing the preliminary interview design and its coding and analysis

3. Editing the primary interviews sketch

4. Selecting participants who have had the experience of attending classes

5. Conducting deep semi-structured interview (the questions are the same for all but other critical questions are asked based on the answers) with the selected item

6 . Transcribing the interviews, coding and analyzing data

\section{Research areas}

The research involved Art teachers in Shiraz and Marvdasht in the Fars province.

The method for selecting participants

The participants were selected by means of snowball sampling method which is continued up to the saturation point (a point after which there is no more useful information). In this research, we could have useful information up to the twelfth person but the sampling was continued up to the twentieth person to increase the credibility of the obtained results.

\section{Data collection tools}

Data collection at the level of phenomenology was first done in the form of field study by interviews with Art teachers and the interviews were codified in table after the confirmation of their authenticity. The data was collected with the help of deep semi-structured interview.

Data analysis method

The data analysis was done using thematic coding in the following stages:

1. Open encoding: means to bring data and phenomena in the form of concepts. At first, phenomena are separated (segmentation). Terms (individual words or a small set of few words) are classified basing on semantic units to attach suspensions and "concepts" (codes). In this research, the available digital and written content was studied first and then important paragraphs related to the research questions were extracted and placed in the table and then detailed concepts were elicited and codified. In the next step, these codes were classified based on the phenomena in the data.

2. Axial encoding: at this stage, the results of open encoding are refined and analyzed. Among the existing results of the open encoding, those which seem to be more useful in next stages were selected and common concepts were shared in the same category. In fact, axial encoding includes the process of organization of more original categories. This involves the complex process of inductive and deductive thinking which is done in several stages. The process is also 
done through comparison and question posing as open encoding. However, axial encoding is more concentrated in using these methods and tries to explore and create categories based on paradigmatic model.

3. Selective encoding: at this stage, axial encoding was developed in a more abstract way and each class was tagged.

\section{Credibility and reliability}

In qualitative research, the credibility of data is considered as the extent to which the results are consistent with reality. In this research, the results were discussed by the experts in the field of art to determine the credibility of the data at the content analysis level after the analysis of the theoretical foundations by subjective encoding. The required corrective actions were taken following the experts' views.

In phenomenology, the three direction method, meaning the use of several information gathering methods, was used to determine the credibility of the results. In addition, reality reconstruction method was also used. The results were presented to participants and their accuracy and completeness were confirmed.

To increase the reliability in this research at the level of phenomenology, we tried to fulfill the following rules and regulations:

1. Interviewing was carried out in a suitable and relaxed environment.

2. At first the investigator declared the aim of the research and then made sure that only interested parties participate in the interview.

3 . Ensuring confidence in the understandability of interview questions for participants.

4. Giving incentives for answering the questions.

5. Typing texts of interviews as soon as possible and providing the opportunity to the respondents to verify them.

6. Analyzing interviews and encoding them.

Discussion

We have designed the Art course model and allocated the following components: objectives, content, learning tools and necessary facilities, time, learning environment, grouping and motivating, learning activities as well as teaching and evaluation methods. Its conditions and characteristics are constituent with the nine partite element in curriculum design (Mehrmohammadi, 1988) (Table 5).

Table 5 .

\section{Art Course Model}

\begin{tabular}{|c|c|}
\hline $\begin{array}{l}\text { The guide model elements } \\
\text { (nine partite elements in } \\
\text { curriculum design) }\end{array}$ & The main conditions and characteristics \\
\hline 1 The objectives & $\begin{array}{l}\text { - the development of Art learning skills: thinking, visual and dramatic literacy, in- } \\
\text { creasing knowledge, etc. }\end{array}$ \\
\hline $\begin{array}{l}\text { 2. The content of the Art } \\
\text { course }\end{array}$ & $\begin{array}{l}\text { - drawing/painting, calligraphy, handicrafts, photography, theater and music with an } \\
\text { emphasis on their properties. }\end{array}$ \\
\hline $\begin{array}{l}\text { 3. Starting the lesson and } \\
\text { grouping students } \\
\text { A: first step }\end{array}$ & $\begin{array}{l}\text { - showing educational videos (the great amount of information is presented within a } \\
\text { short period of time); } \\
\text { - asking to check the cognitive readiness; } \\
\text { - specifying the subject of artistic production; } \\
\text { - choosing the strategies of artistic production; } \\
\text { - dividing students into 5-member groups in each session (drawing/painting, calligraphy } \\
\text { and a mixture of both, handicrafts, photography and a mixture of both, theater and music } \\
\text { and a mixture of both). The students preferring individual work are placed in a separate } \\
\text { group, and students preferring working in small groups (2-3 people) can be satisfied too. }\end{array}$ \\
\hline $\begin{array}{l}\text { 4. Teaching-learning ac- } \\
\text { tivities (the role of a } \\
\text { teacher and a student) } \\
\text { B: intermediate step }\end{array}$ & $\begin{array}{l}\text { - having specific knowledge (scientific and artistic knowledge and educational me- } \\
\text { thods) and a lesson plan; } \\
\text { - taking care of students' achievements; } \\
\text { - answering the questions of students to develop their ideas formation; } \\
\text { - providing learning situations to teach students search for the resources and infor- } \\
\text { mation, work with raw materials and tools, work in a group, ask questions, observe } \\
\text { the activity of the group members and so on. }\end{array}$ \\
\hline $\begin{array}{l}5 \text { and } 6 . \text { Educational envi- } \\
\text { ronment and necessary } \\
\text { facilities }\end{array}$ & $\begin{array}{l}\text { - organizing the art workshop at school; } \\
\text { - decorating chairs and tables and providing the requirements for the group work; } \\
\text { - having a "small library" in the computer with books, CDs of programs, software, } \\
\text { and computer networks; } \\
\text { - creating conditions and opportunities of learning outside the Art workshop for the } \\
\text { real research studies; } \\
\text { - paying attention to establishing a multi-functional environment to facilitate the } \\
\text { access to appropriate activities with determined artistic forms. }\end{array}$ \\
\hline $\begin{array}{l}\text { 7. Appropriate time for } \\
\text { studying }\end{array}$ & - 100 minutes for a session but two separate sessions for 45 minutes are also possible. \\
\hline
\end{tabular}




\begin{tabular}{|c|c|}
\hline $\begin{array}{l}\text { The guide model elements } \\
\text { (nine partite elements in } \\
\text { curriculum design) }\end{array}$ & The main conditions and characteristics \\
\hline $\begin{array}{l}\text { 8. Evaluation and the } \\
\text { improvement of the re- } \\
\text { sults' quality }\end{array}$ & $\begin{array}{l}\text { The evaluation is performed according to the following criteria: } \\
\text { - creativity as the ability to find an appropriate solution, creating uncommon and } \\
\text { non-cliché work of art and so on; } \\
\text { - aesthetics as the ability to choose the most appropriate method for speech, material } \\
\text { selection and so on; } \\
\text { - the relationship between the mind and hand; } \\
\text { - the ability to get involved into the project; } \\
\text { - using educational concepts; } \\
\text { - using available resources and materials; } \\
\text { - the ability to participate in group work and observing skills; } \\
\text { *Homework: students will use the outside class capacities to do some parts of their } \\
\text { homework with the aim of enriching the artistic production, eliminating deficiencies } \\
\text { and weak points with more access to tools and materials. }\end{array}$ \\
\hline $\begin{array}{l}\text { 9. The principles of using } \\
\text { the artistic production } \\
\text { approach (teaching strate- } \\
\text { gy) }\end{array}$ & $\begin{array}{l}\text { Since the education is based on the models of information processing, mix structur- } \\
\text { ing and structural approach, the following cases should be emphasized: } \\
\text { - the conformity of the mentioned approaches and their development according to } \\
\text { the needs of students; } \\
\text { - creating learning environment; } \\
\text { - group work for acquiring idea and subject; } \\
\text { - the relationship between the (art) form of perception (structuring abstract con- } \\
\text { cepts) and expression (structuring concrete concepts). }\end{array}$ \\
\hline
\end{tabular}

Table 6.

The proposed kinds of working with students according to Art teachers' experience

\begin{tabular}{|l|}
\hline Finding random pictures (finding pictures in strip painting) \\
\hline Painting with definite or interesting subject for students \\
\hline Painting for portfolios appropriate to their grade \\
\hline Completing unfinished paintings by students \\
\hline Painting by printing fake or original material \\
\hline Working with clay (pottery) and forming things with it \\
\hline Making things with rubbish papers \\
\hline Making things with leaves or stones \\
\hline Practicing chorus individually or in groups \\
\hline Learning the sounds \\
\hline Telling stories \\
\hline Recalling memories \\
\hline Telling stories by describing a picture \\
\hline Theatre and role playing \\
\hline Mocking sounds in the play \\
\hline
\end{tabular}

\section{Conclusions}

When students participate in the field of arts, they are actually showing individual experiences and their own ideas that are not seen in other fields of learning. Teachers' awareness of the capabilities and weak points of students provide learning experiences that help them to explore their creativity. Teachers should have sufficient knowledge about the arts that is necessary to have judgments about what students have learned (Wright, 2009). We believe that the use of new teaching methods or creating learning opportunities is actually creating curriculum. The teachers are expected fist of all to create various and useful activities and experiences suitable for the elements of the curriculum and students' needs for their better education. Teaching methods, activities and the content of Art course provide the global and local facilities for the Art curriculum. Art course provides an opportunity to develop aesthetics, creativity and the facilitation of learning other courses, the free expression of emotions, and the exploration of emotional and behavioral problems, selfexpression and presenting personal experiences. Eventually, identifying teaching methods and enhancing their qualities can cause reforming and improving Art curriculum, especially in primary school. Given that the major knowledge of students is acquired in the classroom, the classroom environment and teaching quality are the most important factors in students' academic achievements. 


\section{REFERENCES}

1. Deasy, R. (Ed). (2002). Critical links: Learning in the arts and student academic and social development. Washington, DC: Arts Education partnership.

2. Eisner, Elliot (2002). The lessons of teaching Arts, available at learning and arts: crossing boundaries. Proceedings from an. Invitational Meeting for Education, Arts and Youth Funders. Los Angeles.

3. Eisner, Elliot (1998). Educational imagination, Design and Evaluation of school programs: Macmillan college publishing. New York.

4. Huwitz, Al \& Day, Michale (1991). Children and their arts. Regional meeting on Arts Education in the European Countries Canada and the United states of America. Finland.

5. Maleki, H. (2007). Basics lesson planning. Tehran: Organization of School of Social Sciences of Study and Compilation.

6. Mirzabeygi, Ali. (2011). The role of art in education and mental health. Tehran.

7. Mehrmohammadi, Mahmoudi (2011). What, why and how art education. Tehran.

8. Amini, Mohammad (2005). Art education in the field of education. Tehran, Byzh.

9. Rzayy, Manizheh (2004). Review of Harry Brody's aesthetics and its application in education with an emphasis on teaching-learning. Doctor's thesis. Tarbiat Modarres University.
10. Tahery, Hassan (2005). Report evaluating the pilot implementation of elementary art curriculum at first grade of secondary school. Tehran: Office writing textbooks Ministry of Education.

11. Lnkstr, John (1999). Art school. (Abbas Zadeh Trans.). Tehran.

12. Mlky, Hassan (2000). Curriculum guidelines. Tehran: Message ideas.

13. Mhr Mohammadi, Mahmoud (2003). Basic art education "What, why and how". Tehran School Publishing.

14. Mohammadi, Mahmoud (2004). What, why, how art education. Tehran: school.

15. Myrza, BegayHassan (1991). The role of art in education and children's mental appetite. Tehran.

16. Myrzabygy, Ali (2003). The role of art in education and mental health. (4 $4^{\text {th }}$ ed.). Tehran: School publishing.

17. NaghibZadeh, Myrbdalhsyn (1995). Philosophy of Education. Tehran: Tahoori

18. Curtis, T. E. \& Speiker, C. A. (1977). Aesthetic in American education: A position statement. Education and leadership. (35 Vol.).

19. Moon, S. O. (2002). Critical discourse of postmodern aesthetics in contemporary furniture. Retrieved from: http: www.naeareston.org.

Захра Шахнемати, студентка магістратури, факультет педагогіки, Ісламський університет Азад, Ісфахан, Іран,

Зохре Садатманд, дочент, навчально-методичний відділ, Ісламський університет Азад, Ісфахан, Іран, Нарzіз Кеuтiapaй, доиент, навчально-методичний відділ, Ісламський університет Азад, Ісфахан, Іран,

\section{СПЕЦИФІКА ВИКЛАДАННЯ МИСТЕЦЬКИХ ДИСЦИПЛІН У МОЛОДШЙ ШКОЛІ}

У статті розглядаються особливості викладання мистецьких дисциплін молодшим школярам на основі аналізу досвіду вчителів. Мистецтво розвиває в дітях креативність, естетику, а також допомагає самореалізовуватися, виражати почуття та не боятися проявляти себе на інших уроках. Саме задля реформування та покращання викладання важливо вивчати досвід вчителів. Було проведено дослідження, у якому взяли участь 20 викладачів мистецьких дисциплін (кандидатів наук, доцентів) міста Шираз та Марвдашт. Загалом було проаналізовано 12 інтерв'ю, оскільки після 12-го відповіді вчителів повторювалися та не містили нової інформації. Було проаналізовано основні методи та форми роботи для викладання історії мистецтва, мистецької критики, естетики та прикладного мистецтва. За результатами аналізу кодування інтерв’ю було виявлено, що основними формами роботи на уроці є такі: виявлення випадкових зображень (пошук зображень в абстрактному живописі), малювання картин за певною тематикою, завершення незакінчених картин, робота 3 глиною, виготовлення фігурок чи виробів із паперу, листя чи каміння, вигадування та розповідання історій за витвором мистецтва, рольові ігри, оформлення картинної галереї у класі та інші. Також було аналізовано та систематизовано основні ролі вчителя та дітей на уроці мистецтва. Окрім цього, представлено модель уроку мистецтва для дітей молодших класів та описано іiї основні компоненти. Було зроблено висновок, що основну частину знань учні отримують саме в школі під час уроку, отже саме тому якість викладання дисциплін, а також середа класу є найважливішими факторами учнівських досягнень.

Ключові слова: методи викладання, мистецькі дисципліни, мистецтво, викладання, досвід учителів, уроки.

Подано до редакиії 25.12.2016 